\title{
Assessing metal bioaccumulation from estuarine sediments: comparative experimental results for the polychaete Arenicola marina
}

\author{
M. Carmen Casado-Martinez • Brian D. Smith • \\ Philip S. Rainbow
}

Received: 25 November 2011 / Accepted: 19 September 2012 / Published online: 24 November 2012

(C) Springer-Verlag Berlin Heidelberg 2012

\begin{abstract}
Purpose The purpose of this paper is to compare three approaches for providing information on the bioaccumulation potential of metals from contaminated sediments to the deposit-feeding polychaete Arenicola marina.

Materials and methods We present metal (Ag, As, $\mathrm{Cd}, \mathrm{Cu}, \mathrm{Pb}$ and $\mathrm{Zn}$ ) bioaccumulation results from field-collected sediments quantified through direct measurements of bioaccumulated concentrations in A. marina over a period of 30 days under controlled laboratory exposures and compare these results with bioaccumulated metal concentrations in field-collected organisms from the same sites of collection of the sediments used in the laboratory exposures. For the metals for which model parameters are available (Ag, $\mathrm{As}, \mathrm{Cd}$ and $\mathrm{Zn}$ ), we also compare these results with biodynamic model predictions. We considered three UK estuaries characterised by a well-reported history of trace metal contamination and bioavailability in addition to the (control) site of collection of the worms.

Results and discussion The results from laboratory-exposed organisms showed that the standard 28-day exposure duration may be adequate to identify the potential for metal
\end{abstract}

Responsible editor: Wolfgang Ahlf

Electronic supplementary material The online version of this article (doi:10.1007/s11368-012-0611-0) contains supplementary material, which is available to authorized users.

M. C. Casado-Martinez • B. D. Smith • P. S. Rainbow

Department of Zoology, The Natural History Museum,

Cromwell Rd,

London SW7 5BD, UK

M. C. Casado-Martinez $(\bowtie)$

Ecotox Centre, Swiss Center for Applied Ecotoxicology,

Eawag/EPFL,

EPFL-ENAC-IIE-GE Station 2 (GR B0 391),

1015 Lausanne, Switzerland

e-mail: carmen.casado@centreecotox.ch bioaccumulation in this polychaete at the sites considered here. However, the time course of bioaccumulated concentrations and the comparison with measured concentrations in field-collected worms show that a steady state has not been reached, confirming the need for extended exposure periods. The worms showed symptoms of stress in feeding and growth during the initial 10 days of exposure and subsequent partial recovery during the following 20 days, suggesting that stress was not always caused by sediment contamination but that it was likely associated with handling and acclimation. At this last stage of the exposure, a generalised biodynamic model was used to provide estimates of bioaccumulated metal concentrations and net accumulation rates in worms.

Conclusions The results of this study highlight the number of factors that should be considered for the interpretation of bioaccumulated metal concentrations in A. marina under laboratory exposures for contaminated sediment assessment, factors that appear to be common to most deposit-feeding polychaetes. A general biodynamic model proved to be a cost-effective method for an initial estimation of the extent and pattern of metal bioaccumulation under specified exposure conditions.

Keywords Arsenic $\cdot$ Bioaccumulation test $\cdot$ Biodynamic model $\cdot$ Cadmium $\cdot$ Deposit feeder $\cdot$ Silver $\cdot$ Zinc

\section{Introduction}

Bed sediments are often the final repository of environmental pollutants with a strong affinity for particles and may accumulate concentrations so high as to represent a risk to organisms, especially deposit-feeding sediment infauna. The risk assessment process for contaminated sediment used in regulatory and monitoring programmes uses the 
physico-chemical characterisation of sediments, toxicity testing, benthic surveys and the bioaccumulation/biomagnification potential of contaminants (e.g., Chapman and Anderson 2005). Biomagnification is most commonly considered for persistent organic contaminants (Mackay and Fraser 2000), whereas biomagnification of metals is apparently food web and metal specific (Barwick and Maher 2003; Croteau et al. 2005; Cheung and Wang 2008; Jæger et al. 2009). Nevertheless, marine organisms can accumulate metal concentrations in their tissues that may threaten the health of organisms higher in the food chain through trophic transfer, and evidence exists of adverse effects in marine top predators associated with metal-rich diets (Boyle et al. 2008; Cheung and Wang 2008).

Bioaccumulation of contaminants from sediment can be measured directly through the collection of organisms from the field, transplantation studies and laboratory tests, or it can be predicted using models (US EPA 2000; Fairbrother et al. 2007). Historically common among the models are bioconcentration/bioaccumulation factors (BSAF when referred to sediments) and the acid-volatile sulfide model for metals, which assumes that metals forming highly insoluble metal sulfides in sediments are unavailable to infaunal biota (Fairbrother et al. 2007; ICMM 2007). Both of these modelling approaches for metals have been criticised as flawed given an understanding of the physiology and behaviour of burrowing animals, especially those ingesting sediment (Lee et al. 2000; De Jonge et al. 2009). When appropriate data are available, the use of kinetic-based models such as biodynamic modelling is considered to be a more defensible alternative (Fairbrother et al. 2007; ICMM 2007).

Direct measurements of bioaccumulated metal concentrations account for physiological differences between sediment-affected organisms and take into account geochemical factors (De Jonge et al. 2009; Van Geest et al. 2011). While field studies offer information on real environmental situations, bioaccumulation bioassays are useful to obtain direct measurements for assessment of hypothetical situations or when the habitat under study is otherwise (to be) altered, for example by dredging activities, and obtaining field-collected tissue is not possible (Van Geest et al. 2011). In addition to standardisation of protocols, field validation of bioaccumulation tests is needed if quantitative estimates of exposure are to be used with confidence in ecological risk assessment and decision-making (ASTM 2010; Van Geest et al. 2010).

Arenicola marina is a well-studied polychaete in coastal areas of the North Atlantic. A. marina lives in and feeds on sediment. It provides an important food source for fish and invertebrate species, thus potentially contributing to the trophic transfer of sediment-bound metals to higher levels in the food chain. The use of A. marina as a test organism has been extended and supported by several recommendations for acute toxicity testing (e.g., OSPAR 1995; Thain and Bifield 2001). Its use has been tested in the development of longer-term assays which measure effects on sublethal endpoints, considered more relevant to predicting impacts at the population level (Allen et al. 2007), and several biomarkers are being validated in laboratory-exposed organisms and organisms from field toxicity bioassays using benthic cages (RamosGomez et al. 2011a, b). A. marina has been also used in bioaccumulation and toxicity studies of organic (Thain et al. 1997; Kaag et al. 1998; Timmermann and Andersen 2003; Morales-Caselles et al. 2008) and metal contaminants (Bernds et al. 1998; Casado-Martinez et al. 2010a; Kalman et al. 2012), and several studies have used A. marina as a model organism for describing the bioavailability of sediment-bound contaminants to deposit feeders in in vitro studies (Chen and Mayer 1999; Lawrence et al. 1999; Turner et al. 2008).

Recently, we have described the bioaccumulation of trace metals ( $\mathrm{Ag}, \mathrm{As}, \mathrm{Cd}$ and $\mathrm{Zn}$ ) from water and sediment in $A$. marina by means of biodynamic modelling, showing that ingested sediment is an important (typically much the major) uptake route (Casado-Martinez et al. 2009a, 2010b). Dynamic modelling improves predictions of metal bioaccumulation in aquatic organisms because it incorporates different exposure routes (i.e., water and diet) and the dynamic nature of physiological metal bioaccumulation processes (Luoma and Rainbow 2005). The calibration and validation of model predictions against field measurements corroborated the validity of model assumptions and supported the use of biodynamic modelling to predict metal bioaccumulation in this deposit-feeding polychaete (Casado-Martinez et al. 2009b). Here, we present metal bioaccumulation results from field-collected sediments quantified through direct measurements of bioaccumulated concentrations in $A$. marina over a period of 30 days under controlled laboratory exposures and compare these results with bioaccumulated metal concentrations in field-collected organisms from the same sites of collection of the sediments used in the laboratory exposures. These results are also compared with biodynamic predictions for the bioaccumulation of the metals for which model parameters are available (Ag, As, Cd and $\mathrm{Zn}$ ), which are also used for a better interpretation of laboratory bioaccumulation test results.

\section{Materials and methods}

\subsection{Laboratory bioaccumulation studies}

\subsubsection{Collection of worms and sediments}

Worms were collected from the Two Tree Island $\left(051^{\circ} 31.92^{\prime}\right.$ $\mathrm{N}, 00^{\circ} 37.62^{\prime} \mathrm{E}$ ) in the outer Thames estuary in SE England by digging intertidally. Two different batches of experiments 
were carried out, a first one in September 2008 (exposure to Thames, Dulas Bay and Gannel sediments) and a second one in July 2009 (exposure to Restronguet Creek sediments). The worms were transported to the laboratory in a cool box and were maintained in the same seawater and conditions used in all laboratory exposures - artificial seawater (Tropic Marine (TM), Tropicarium Buchschlag, Dreieich, Germany) at a salinity of 33 at $10{ }^{\circ} \mathrm{C}$ - until they were used in experiments.

Sediments were collected at different UK estuaries characterised by a well-reported history of trace metal contamination and bioavailability: the Gannel estuary $\left(050^{\circ} 20.25^{\prime} \mathrm{N}, 05^{\circ} 05.93^{\prime} \mathrm{W}\right)$ and Restronguet Creek $\left(050^{\circ} 11.51^{\prime} \mathrm{N}, 05^{\circ} 03.50^{\prime} \mathrm{W}\right)$ in Cornwall in SW England and Dulas Bay $\left(053^{\circ} 22.30^{\prime} \mathrm{N}, 04^{\circ} 16.73^{\prime} \mathrm{W}\right)$ in Anglesey, north Wales. Sediments were also collected from the site of worm collection in the outer Thames Estuary in SE England, which were used as an experimental control. Oxic surface sediments (approximately 401 each from the top $10 \mathrm{~cm}$ ) were collected with a spade and placed in clean plastic buckets for transport to the laboratory, where a subsample was taken for characterisation of physico-chemical properties. The rest of the sediment was kept at $4{ }^{\circ} \mathrm{C}$ in the dark until use in the exposures, always in the following month after collection (US EPA 2000).

\subsubsection{Experimental setup}

PVC cylinders, $12 \mathrm{~cm}$ in height and $10 \mathrm{~cm}$ in diameter, were filled with test sediments to a depth of $10 \mathrm{~cm}$, and multiple cylinders were placed in larger plastic boxes filled with TM to reach $2 \mathrm{~cm}$ above the cylinders. The overlying water was aerated and maintained at $10 \pm 2{ }^{\circ} \mathrm{C}$ during the exposure duration and salinity of $33 \pm 2$ by adding distilled water. Overlying water was renewed on days 10, 20 and 30.

Two days after the experimental setup, a single worm was placed in each cylinder. Worms that had not burrowed during the first $24 \mathrm{~h}$ were replaced by new worms. Worms were inspected at 24-48-h intervals for casting, burrowing or mortality, and any dead worms on the sediment surface were removed. On days 10, 20 and 30, five worms were sampled for the analysis of metal content. Worms were rinsed in $\mathrm{TM}$ and were placed in $50 \mathrm{ml} \mathrm{TM}$ for $2 \mathrm{~h}$ to eliminate surface-adsorbed metals. Then, the worms were dried in tissue paper and were frozen at $-20{ }^{\circ} \mathrm{C}$. The worms were dissected to remove any sediment present in the gut, dried to constant weight at $60{ }^{\circ} \mathrm{C}$ and digested in concentrated nitric acid (Aristar grade, Merck) at $100{ }^{\circ} \mathrm{C}$ (hot acid reflux). Each digest was made up to a known volume with double-distilled water for trace metal analysis. On the day the exposure was initiated, $10 \mathrm{ml}$ of overlying water near the sediment surface was sampled from each exposure chamber and acidified with concentrated nitric acid for the quantification of dissolved trace metal concentrations using the same technique as for sediments and worm extracts.

\subsubsection{Physico-chemical measurements}

Sediment samples were sieved through a $125-\mu \mathrm{m}$ stainless steel mesh with distilled water, and the two separated fractions were dried to constant weight at $60{ }^{\circ} \mathrm{C}$ to provide an estimate of the proportion of fines in the sample. The dried fine fraction was ground to a fine powder with mortar and pestle. Five-gram replicates of the fine fraction were digested for metal analysis by refluxing in $10 \mathrm{ml}$ concentrated $\mathrm{HNO}_{3}$ before evaporation to dryness and reconstitution in $0.6 \mathrm{~N} \mathrm{HCl}$. Further $0.5 \mathrm{~g}$ replicates of the fine sediment samples were extracted in $10 \mathrm{ml}$ of $0.6 \mathrm{~N} \mathrm{HCl}$ for $2 \mathrm{~h}$ at room temperature. Organic matter (OM) content was estimated as weight loss after ignition at $550{ }^{\circ} \mathrm{C}$ for 30 min.

Analysis of worm and sediment digests was carried out on a Vista-Pro CCD simultaneous inductively coupled plasma-optical emission spectrometer. Comparative samples of Standard Reference Material for sediment (MESS 3, National Research Council of Canada, Ottawa, Canada) and mussel tissue (ERM CE278, Institute of Reference Materials and Measurements, Geel, Belgium) and blanks were processed and analysed simultaneously. Differences observed for sediment reference material are attributable to the different acid extractions used and are consistent with results found in the literature (Townsend et al. 2007; Casado-Martinez et al. 2009b). All metal concentration data are expressed in terms of dry weight. Differences are considered as statistically significant at $p<0.05$.

\subsection{Field data}

Sediments and worms were collected from the Thames and Gannel estuaries and Dulas Bay in May or June 2008 at the same sites and following the same sampling procedure as for the laboratory tests. No field data are available for Restronguet Creek worms because the creek does not host any population of $A$. marina. Digestion and analysis of worms and sediments followed the same procedures as for the laboratory bioaccumulation study. The summaries of bioaccumulated concentrations of $\mathrm{Ag}$ and $\mathrm{Cd}$ used for comparisons are those estimated for a standard-sized worm of $0.3 \mathrm{~g}$ dry weight, as opposed to mean concentrations, in order to allow for the significant variation of individual size of the worms between collection sites and the effect of body size on accumulated metal concentrations. Statistical differences are considered as significant at $p<0.05$. Full information on the procedures and data can be found elsewhere (Casado-Martinez et al. 2009b, 2010b). 


\subsection{Biodynamic modelling}

The variation of accumulated metal in worms with time may be described as:

$\mathrm{d} C_{\mathrm{O}} / \mathrm{d} t=\left(k_{\mathrm{u}} C_{\mathrm{W}}-k_{\mathrm{ew}} C_{\mathrm{OW}}\right)+\left(\mathrm{AE} \mathrm{IR} C_{\mathrm{S}}-k_{\mathrm{es}} C_{\mathrm{OS}}\right)$

where $C_{\mathrm{O}}\left(\mu \mathrm{gg}^{-1}\right.$ dry weight) is the total amount of metal accumulated by the organism, subdivisible into $C_{\mathrm{OW}}$, the metal accumulated after uptake from water, and $C_{\mathrm{OS}}$, the metal accumulated from sediment ingested as food; $k_{\mathrm{u}}$ $\left(\mu \mathrm{gg}^{-1} \mathrm{day}^{-1}\right.$ per $\mu \mathrm{gl}^{-1}$ or $\left.\mathrm{gg}^{-1} \mathrm{day}^{-1}\right)$ is the uptake rate constant from water; $C_{\mathrm{W}}\left(\mu \mathrm{gl}^{-1}\right)$ is the concentration in solution; $k_{\mathrm{ew}}\left(\mathrm{day}^{-1}\right)$ is the rate constant of loss of metal taken up from solution; $C_{\mathrm{S}}\left(\mu \mathrm{gg}^{-1}\right)$ is the concentration in the sediment ingested as food; IR $\left(\mathrm{gg}^{-1} \mathrm{day}^{-1}\right)$ is the ingestion rate; $\mathrm{AE}(\%)$ is the assimilation efficiency and $k_{\mathrm{es}}$ $\left(\right.$ day $\left.^{-1}\right)$ is the loss rate constant of metals assimilated from the sediment as food. For a certain exposure period, the gain or loss of metal can be calculated as:

$\Delta C_{\mathrm{O} t}=\left(k_{\mathrm{u}} C_{\mathrm{W}} / k_{\mathrm{ew}}\right)\left(1-e^{k_{\mathrm{ew}} t}\right)+\left(\mathrm{AE} \mathrm{IR} C_{\mathrm{S}} / k_{\mathrm{es}}\right)\left(1-e^{k_{\mathrm{es}} t}\right)$

$\Delta C_{\mathrm{Ot}}$ added to the initial background concentration prior to exposure (day 0 ) gives a final bioaccumulated concentration at time $t$. This background concentration $\left(C_{0}\right)$ should undergo the same concentration changes (i.e., efflux; Bennett et al. 2011) described by $k_{\text {es }}$ and/or $k_{\text {ew }}$ depending on its origin from water or food and the prevalence of each route of uptake-for A. marina, we used $k_{\text {es }}$ values assuming that most of the accumulated metals are taken up from ingested sediment according to previous estimates (CasadoMartinez et al. 2009b, 2010b)—as

$C_{0 t}=C_{0} e^{-\left(k_{e s} t\right)}$

A complete description of the selection of values used for the construction of the generic model can be found elsewhere (Casado-Martinez et al. 2009b, 2010b). A generic model was constructed using the values of the physiological parameters $k_{\mathrm{u}}, k_{\mathrm{ew}}, \mathrm{AE}$ and $k_{\mathrm{es}}$ obtained empirically using radiotracers (i.e., ${ }^{73} \mathrm{As},{ }^{110 \mathrm{M}} \mathrm{Ag},{ }^{109} \mathrm{Cd}$ and ${ }^{65} \mathrm{Zn}$ ) from laboratory exposures for two different populations under the same conditions as in the bioaccumulation tests used in this study (i.e., temperature, salinity, same overlying water; Casado-Martinez et al. 2009a, 2010b), together with sets of sediment physico-chemical parameters commonly obtained in most sediment characterizations (Tables 1 and 2). The dissolved concentrations $\left(C_{\mathrm{W}}\right)$ used in the modelling were obtained after scaling the range of standard concentrations considered in our previous exercises to the concentrations measured in sediments, assuming that $A$. marina is exposed to an unknown mixture of overlying and interstitial water (Casado-Martinez et al. 2010b;
Rainbow et al. 2011). The metal concentrations in ingested sediments $\left(C_{\mathrm{S}}\right)$ were those measured in sediments after strong $\left(\mathrm{HNO}_{3}\right)$ or weak $(\mathrm{HCl})$ acid extraction depending on our previous calibration exercises $\left(\mathrm{HNO}_{3}\right.$ for $\mathrm{Ag}, \mathrm{Cd}$ and $\mathrm{Zn} ; \mathrm{HCl}$ for As). Site-specific ingestion rates (IRs) were calculated taking into account the OM content measured in the fine sediment fraction $(<125 \mu \mathrm{m})$ for a size of worm corresponding to the mean weight of the individuals exposed to each of the sediments according to the model developed by Cammen (1980). For modelling the bioaccumulation of $\mathrm{Ag}, \mathrm{Cd}$ and $\mathrm{Zn}$, we expressed the calculated IR as grams of OM ingested per gram of organism per day, with the assumption that A. marina only subjects the organic matter in the sediment to digestive processing (Casado-Martinez et al. 2009a, b). This assumption gave the best predicted fit to measured concentrations in fieldcollected worms for these three metals (Casado-Martinez et al. 2009a, b). For As, the IRs are expressed in terms of gram of total dry sediment per gram of organism per day, this different assumption giving the best predicted fit to measured field concentrations (Casado-Martinez et al. 2010b). When these IRs are coupled with the metal concentrations measured in the whole fine fraction of the sediment (after $\mathrm{HNO}_{3}$ extraction as for $\mathrm{Ag}, \mathrm{Cd}$ and $\mathrm{Zn}$ or after $\mathrm{HCl}$ extraction as for As), we further assume that the metal is distributed homogeneously among the different binding phases (OM, Fe/Mn oxides, etc.) and that the respective extraction procedure identified above gives the best proxy for metal bioavailability from sediments to the worm through desorption in the gut for the metal concerned (Casado-Martinez et al. 2010b). For Ag, Cd and Zn, we are assuming that only the metal bound to $\mathrm{OM}$ is processed and therefore susceptible to bioaccumulation- - . marina adjusting their feeding rate to the organic component of the sediment fine fraction (Casado-Martinez et al. 2009a) whereas for As we assume that both organic and inorganic phases of the sediment ingested are relevant sources for As bioaccumulation (Casado-Martinez et al. 2010b). For As, we scaled the $\mathrm{AE}$ and water concentrations to the $\mathrm{Fe}$ concentration measured in the Thames sediments, our reference site used for the development of the physiological parameters of As uptake and elimination, according to the normalisation factor $(S)$ developed by Casado-Martinez et al. (2010b):

$S=($ Thames $\mathrm{HCl}-\mathrm{Fe}$ sediment concentration $)$

$$
\text { / (site } \mathrm{HCl}-\mathrm{Fe} \text { sediment concentration })
$$

where Thames $\mathrm{HCl}-\mathrm{Fe}$ sediment concentration and site $\mathrm{HCl}-\mathrm{Fe}$ sediment concentration are the $\mathrm{Fe}$ concentrations measured in the Thames sediments or the sediments from the site under consideration, respectively, after extraction with $\mathrm{HCl}$. 
Table 1 Sediment properties (percentages of sediment with grain size $<125 \mu \mathrm{m}$ (fine fraction) and $\mathrm{OM}$ ) and concentrations of $\mathrm{Ag}, \mathrm{As}, \mathrm{Cd}$, $\mathrm{Zn}, \mathrm{Cu}, \mathrm{Pb}$ and $\mathrm{Fe}$ in this fine fraction of the sediments used in the

\begin{tabular}{|c|c|c|c|c|c|}
\hline & & Thames estuary & Gannel estuary & Dulas Bay & Restronguet Creek \\
\hline Fine fraction, $\%$ & & 68 & 8 & 1 & 1 \\
\hline $\mathrm{OM}, \%$ & & $4 \pm 0.34$ & $9 \pm 0$ & $17 \pm 2$ & $14 \pm 1$ \\
\hline \multirow[t]{2}{*}{$\mathrm{Ag}$} & $\mathrm{HNO}_{3}$ & $0.28 \pm 0.01$ & $0.17 \pm 0.01$ & $<0.05$ & $0.56 \pm 0.01$ \\
\hline & $\mathrm{HCl}$ & $0.18 \pm 0.01$ & $<0.05$ & $<0.05$ & $0.46 \pm 0.01$ \\
\hline \multirow[t]{2}{*}{ As } & $\mathrm{HNO}_{3}$ & $5.95 \pm 0.11$ & $42.0 \pm 2.10$ & $18.0 \pm 8.70$ & $1,160 \pm 5.85$ \\
\hline & $\mathrm{HCl}$ & $1.89 \pm 0.06$ & $14.4 \pm 0.57$ & $6.17 \pm 0.44$ & $717 \pm 0.28$ \\
\hline \multirow[t]{2}{*}{$\mathrm{Cd}$} & $\mathrm{HNO}_{3}$ & $0.78 \pm 0.02$ & $1.41 \pm 0.03$ & $0.37 \pm 0.02$ & $<0.43$ \\
\hline & $\mathrm{HCl}$ & $0.22 \pm 0.01$ & $0.27 \pm 0.01$ & $<0.17$ & $<0.43$ \\
\hline \multirow[t]{2}{*}{$\mathrm{Zn}$} & $\mathrm{HNO}_{3}$ & $54.8 \pm 4.15$ & $214 \pm 5.76$ & $205 \pm 0.75$ & $954 \pm 9.11$ \\
\hline & $\mathrm{HCl}$ & $32.6 \pm 0.03$ & $146 \pm 4.80$ & $156 \pm 0.17$ & $1,087 \pm 11.9$ \\
\hline \multirow[t]{2}{*}{$\mathrm{Cu}$} & $\mathrm{HNO}_{3}$ & $9.20 \pm 0.03$ & $35.8 \pm 0.61$ & $108 \pm 3.41$ & $807 \pm 6.11$ \\
\hline & $\mathrm{HCl}$ & $5.36 \pm 0.05$ & $15.7 \pm 0.32$ & $88.3 \pm 0.45$ & $594 \pm 10.0$ \\
\hline \multirow[t]{2}{*}{$\mathrm{Pb}$} & $\mathrm{HNO}_{3}$ & $16.2 \pm 0.02$ & $113 \pm 4.25$ & $9.77 \pm 0.10$ & $115 \pm 1.00$ \\
\hline & $\mathrm{HCl}$ & $14.7 \pm 0.13$ & $116 \pm 4.21$ & $8.81 \pm 0.01$ & $115 \pm 1.28$ \\
\hline \multirow[t]{2}{*}{$\mathrm{Fe}$} & $\mathrm{HNO}_{3}$ & $10,279 \pm 483$ & $13,017 \pm 181$ & $5,624 \pm 364$ & $18,268 \pm 3,284$ \\
\hline & $\mathrm{HCl}$ & $2,019 \pm 85$ & $1,825 \pm 96$ & $1,386 \pm 163$ & $11,054 \pm 21$ \\
\hline
\end{tabular}

laboratory exposures after near total $\left(\mathrm{HNO}_{3}\right)$ and partial $(\mathrm{HCl})$ extrac-

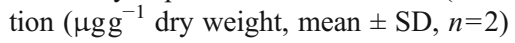




\section{Results}

\subsection{Laboratory bioaccumulation studies}

\subsubsection{Sediment characteristics and overlying water concentrations}

Table 1 summarises the sediment properties ( $\%$ of sediment with grain size $<125 \mu \mathrm{m}$ and $\%$ of $\mathrm{OM}$ ) and the concentrations of $\mathrm{Ag}, \mathrm{As}, \mathrm{Cd}, \mathrm{Cu}, \mathrm{Pb}, \mathrm{Zn}$ and $\mathrm{Fe}$ in the fine fraction of the sediments after extraction with concentrated $\mathrm{HNO}_{3}$ and partial extraction with $0.6 \mathrm{~N} \mathrm{HCl}$. Sediments from the Gannel estuary, Dulas Bay and Restronguet Creek were sandy with a proportion of OM in the fine sediment fraction between 9 and $17 \%$. The sediments from the Thames estuary, which is the sediment that hosted the population of worms used in the laboratory exposures, consisted of a sandy mud with $4 \%$ OM content in the fine fraction.

The fine fraction of the sediments from the Thames presented the lowest concentrations of As and $\mathrm{Zn}$ and intermediate concentrations of $\mathrm{Ag}$ and $\mathrm{Cd}$ compared to the other sediments. The Restronguet Creek sediments have the highest concentrations of $\mathrm{Ag}$, As and $\mathrm{Zn}$, whereas the $\mathrm{Cd}$ concentrations were below the detection limit. As and $\mathrm{Cd}$ were higher in the Gannel estuary than at Dulas Bay, whereas the $\mathrm{Ag}$ and $\mathrm{Zn}$ concentrations were similar at both sites. The $\mathrm{Cu}$ concentrations were very high at Restronguet Creek and Dulas Bay, and the $\mathrm{Pb}$ concentrations were significantly higher at Restronguet Creek and the Gannel estuary than at the rest of the sites.

The concentrations of $\mathrm{Ag}, \mathrm{Cd}$ and $\mathrm{Pb}$ in overlying water before introduction of the worms were always below the detection limit $\left(2 \mu \mathrm{g} \mathrm{Ag} 1^{-1}, 7 \mu \mathrm{g} \mathrm{Cd} l^{-1}\right.$ and $\left.20 \mu \mathrm{g} \mathrm{Pb} \mathrm{l}^{-1}\right)$. Arsenic concentrations were only measured at quantifiable levels (detection limit is $30 \mu \mathrm{g} \mathrm{As} \mathrm{l}^{-1}$ ) in the Restronguet Creek exposure, with a concentration of $36 \pm 2 \mu \mathrm{g} \mathrm{As} 1^{-1}$, whereas the $\mathrm{Zn}$ concentrations were $89 \pm 1 \mu \mathrm{g} \mathrm{Zn} \mathrm{l^{-1 }}$ in the Restronguet Creek exposure, $77 \pm 1.7 \mu \mathrm{g} \mathrm{Zn} 1^{-1}$ in the Dulas Bay exposure and $18 \pm 2 \mu \mathrm{g} \mathrm{Zn} 1^{-1}$ in the Gannel. $\mathrm{Zn}$ concentration in overlying water in the Thames estuary exposure was $<5 \mu \mathrm{g} \mathrm{Zn} \mathrm{Z}^{-1}$.

\subsubsection{Burial, feeding activity and mortality}

The accumulated mean survival of $A$. marina was $\geq 80 \%$ and adequate for bioaccumulation bioassays (US EPA 2000; Van Geest et al. 2010) in all but the Gannel sediment, where the accumulated mortality was $30 \%$ at the end of the 30-day exposure. Worms buried into sediments immediately after introduction to the test chambers, and no differences in initial worm burrowing behaviour were found between the different sediments. Some worms started to produce casts already after $24 \mathrm{~h}$ of exposure, indicating active feeding, whereas other worms did not produce any cast until day 3 . The number of worms actively feeding increased over time as the worms acclimated to the test sediments, and almost all of the worms that fed during exposure were already feeding by the third day. The percentage of worms that actively fed during the 30-day exposure period was $95 \%$ for the Thames sediments, $84 \%$ for the Gannel, $71 \%$ for Dulas Bay and $70 \%$ for Restronguet Creek. Only worms that were actively feeding were used for quantification of bioaccumulated metal concentrations.

Even if the individuals were actively feeding during the experiments, they lost part of their body weight compared to that measured before exposure was started. Over the 30-day exposure period, the change in total body wet weight of worms ranged from -35 to $+20 \%$, with mean body weights being 90,87 and $81 \%$ of initial weight when exposed to the Thames, Gannel and Dulas Bay sediments, respectively. Individual body weight was more homogeneous in worms exposed to Restronguet Creek sediments, but the average change in total body wet weight of worms was $-35 \%$ at the end of the 30-day exposure.

\subsubsection{Metal bioaccumulation}

The bioaccumulated concentrations in A. marina exposed to the different sediments over 30 days of exposure are summarised in Fig. 1. We report two different initial concentrations in experimental worms collected from the Thames estuary according to the two different batches of experiments carried out; the first batch tested the Thames, Gannel and Dulas Bay sediments, whereas the second batch tested the Restronguet Creek sediments. In accordance with the very high metal concentrations in the Restronguet Creek sediment, worms exposed to this sediment showed a statistically significant increase in the concentrations of $\mathrm{As}, \mathrm{Cu}, \mathrm{Pb}$ and $\mathrm{Zn}$ in their tissues after only 10 days of exposure when compared to concentrations on day 0 . Bioaccumulated metal concentrations showed a progressive increase during the following 20 days of exposure and reached maximum levels on day 30 .

Worms exposed to sediments from the Gannel estuary and Dulas Bay showed an increase in the bioaccumulated concentrations of those metals that showed high concentrations in these sediments (see Table 1). Worms exposed to the Gannel sediment showed a statistically significant increase in $\mathrm{As}, \mathrm{Cd}$ and $\mathrm{Pb}$ bioaccumulated concentrations on day 30 , but bioaccumulated metal concentrations on days 10 and 20 did not show a clear increasing trend. Similarly, the bioaccumulated $\mathrm{Cu}$ concentrations in worms were significantly $(p<0.05)$ raised after 30 days of exposure to Dulas Bay sediments but not before.

In general, most metals studied showed an increasing accumulation throughout the last 10 days of exposure. The bioaccumulated concentrations of $\mathrm{Zn}$ showed a different 

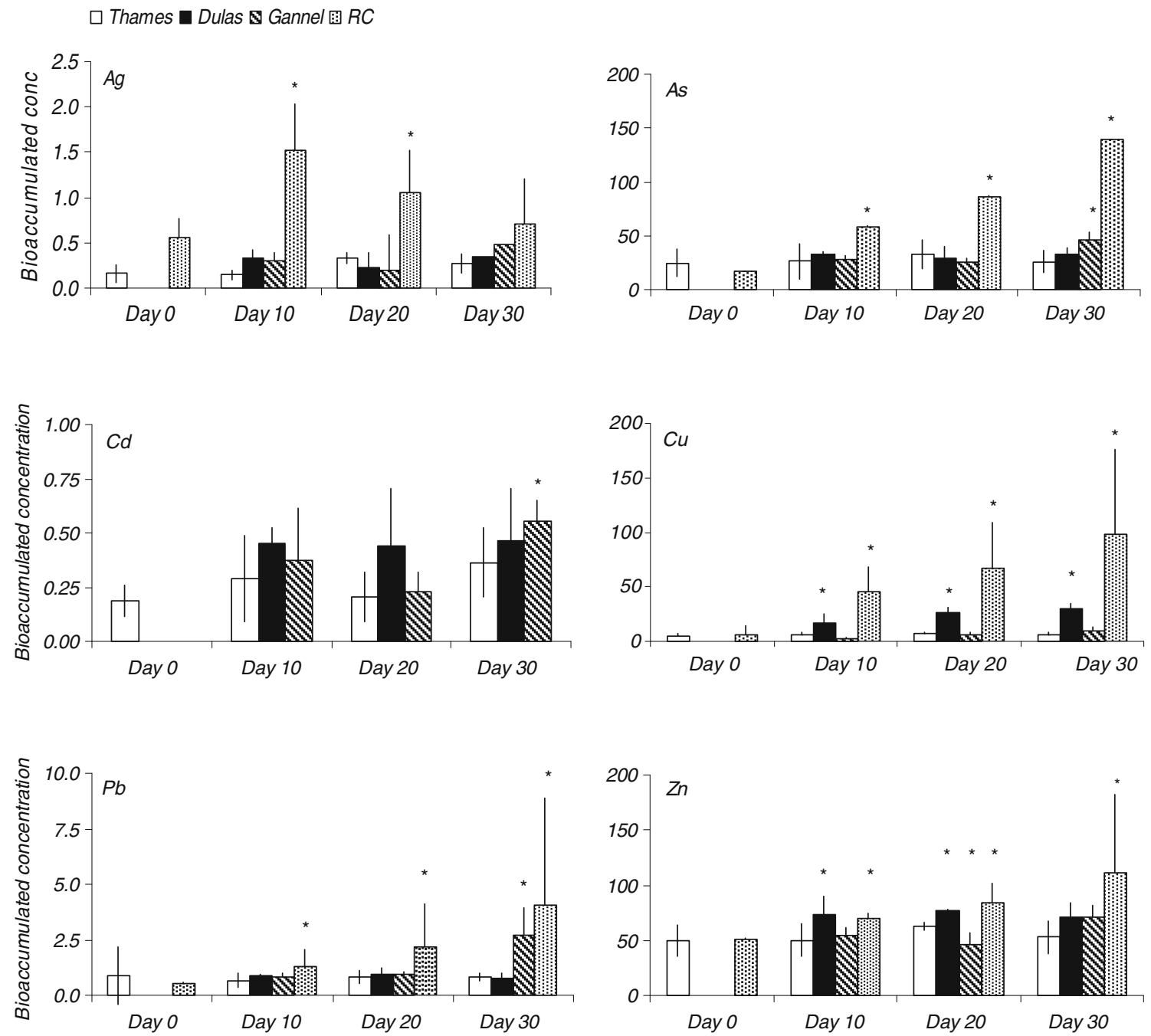

Fig. 1 Mean and standard deviation of bioaccumulated metal concentrations $\left(\mu \mathrm{gg}^{-1}\right)$ in $A$. marina collected from the Thames estuary over 30 days of exposure to estuarine sediments $(n=3-5)$. Bioaccumulated

concentrations on day 0 for the Gannel and Dulas Bay exposures are those shown for the Thames. Asterisk indicates statistical difference from metal concentration in lugworms on day 0 at $p<0.05$

pattern. Worms showed a statistically significant increase in tissue concentrations on day 10 of exposure to the Gannel estuary and Restronguet Creek sediments, whereas a significant increase was also observed on day 20 upon exposure to Dulas Bay sediments. The $\mathrm{Zn}$ concentrations in worms exposed to all sediments showed an increase on day 30 compared to those measured in worms exposed to the Thames sediment (the control exposure), but the increase was only statistically significant in worms exposed to the Restronguet Creek sediments.

In this study, we also considered the exposure of worms to the Thames estuary sediments from the site of collection of worms as a control exposure. Although the bioaccumulated metal concentrations showed a certain degree of variation over the exposure period, no statistically significant increase or decrease was registered compared to the concentrations measured in worms before sediment exposure.

\subsection{Comparison between laboratory and field data}

The comparison of bioaccumulated metal concentrations between field-collected and laboratory-exposed A. marina is summarised for the three sites in Fig. 2a (field data are not available for Restronguet Creek). The plot shows that only a small number of points fall out of the twofold variation range, and most of them fall below the 1:1 relationship, indicating that laboratory-measured bioaccumulated concentrations were most commonly in the range of or lower than field-measured concentrations. The regression of laboratory versus field bioaccumulated concentrations for the data from the Thames estuary followed the 1:1 relationship, with a slope of $1.06\left(R^{2}=0.99\right.$; Fig. 2a). The slope of the regression of data from the Gannel estuary was $0.74\left(R^{2}=0.90\right)$, whereas that for Dulas Bay was 0.57 $\left(R^{2}=0.62\right)$. 

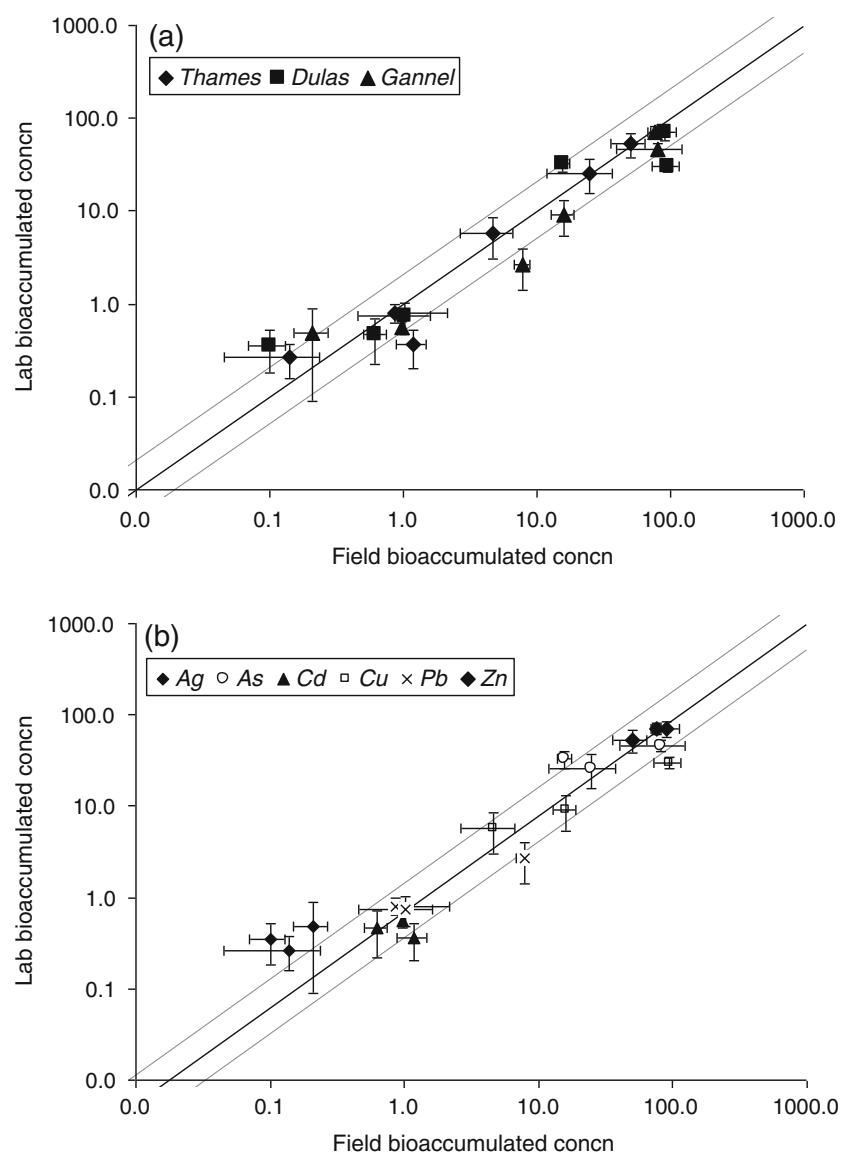

Fig. 2 Laboratory versus field bioaccumulated metal concentrations $\left(\mu \mathrm{gg}^{-1}\right)$ in A. marina for the three studied sites (a) and for the different metals analysed (b). Data are mean and standard deviation. Lines represent the 1:1 relationship and a deviation of $2 \times$ above or below

Bioaccumulated concentrations of $\mathrm{Ag}$ measured in laboratory-exposed organisms (see Fig. 2b) were most often higher than those measured in field-collected worms, whereas the concentrations of $\mathrm{As}, \mathrm{Cd}, \mathrm{Cu}$ and $\mathrm{Pb}$ deviated from the 1:1 relationship at increasing bioaccumulated field concentrations. The $\mathrm{Cu}$ concentrations measured in worms exposed to the Dulas Bay sediments are $\sim 30 \%$ of those measured in field-collected worms. The concentrations of $\mathrm{Pb}$ in A. marina exposed to the Gannel sediments in the laboratory were $\sim 30 \%$ of those measured in field-collected worms, and this percentage increases to $\sim 55 \%$ for As. The data for $\mathrm{Zn}$ followed a 1:1 relationship, indicating that laboratory-measured bioaccumulated concentrations were in the range of field-measured concentrations.

Since the samples used to obtain the field and laboratory data were not collected synoptically, it is possible that differences in bioaccumulated concentrations are associated with different metal concentrations in sediments. A comparison of BSAFs (see data in Table S1 of the "Electronic supplementary material"), calculated for the laboratory and field exposures as the ratio between the bioaccumulated concentration for a certain metal and the concentration of the metal in the sediment, shows how the lack of agreement of bioaccumulated concentrations of $\mathrm{Ag}$ was associated with differences in the sediment concentrations only in the Thames exposure but not in the Gannel and Dulas exposures, which showed higher bioaccumulated concentrations in laboratory-exposed worms than in field-collected worms. The disagreement in the bioaccumulation of $\mathrm{Cu}$ in the Gannel sediments is also associated with differences in the sediment concentrations according to a BSAF of 0.58 calculated for both the field and laboratory data. However, the difference in the bioaccumulated $\mathrm{Cu}$ concentrations in the Dulas Bay was not associated with sediment concentrations, with corresponding BSAFs of 0.28 and 0.43 for the laboratory and field data, respectively. The bioaccumulated concentrations and corresponding BSAFs for $\mathrm{As}, \mathrm{Cd}, \mathrm{Zn}$ and especially $\mathrm{Pb}$ are consistently lower in laboratory-exposed than in field-collected worms.

\subsection{Comparison between laboratory exposure data and biodynamic modelling}

The comparison of bioaccumulated concentrations in laboratory-exposed A. marina and biodynamic predictions of bioaccumulated concentrations of the four metals $\mathrm{Ag}$, As, $\mathrm{Cd}$ and $\mathrm{Zn}$ after 10, 20 and 30 days of exposure is summarised in Fig. 3 for the metals of concern at each site (namely, As and $\mathrm{Zn}$ for Dulas Bay; As, Cd and Zn for the Gannel; and $\mathrm{Ag}$, As and $\mathrm{Zn}$ for Restronguet Creek). The plot shows that only a small number of points fall out of the twofold

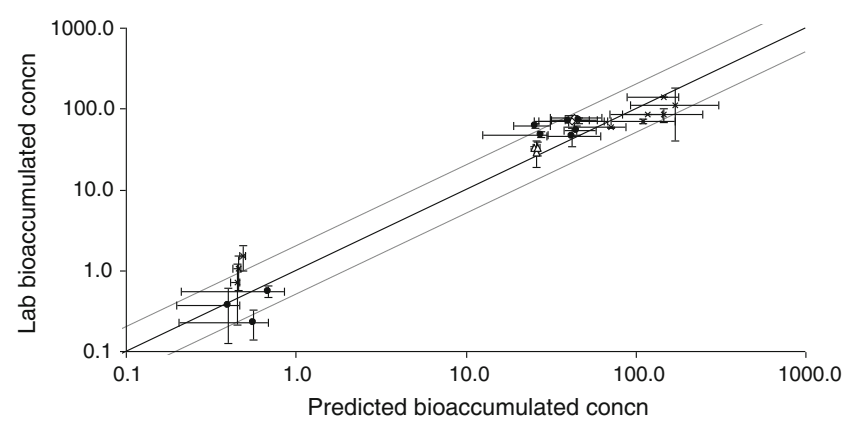

Fig. 3 Comparison between measured bioaccumulated concentrations of Ag, As, Cd and $\mathrm{Zn}$ in A. marina exposed in the laboratory for 10, 20 and 30 days to field-collected sediments (mean \pm standard deviation) and model-predicted concentrations $\left(\mu \mathrm{gg}^{-1}\right)$. The predicted concentrations have been developed using a generalised model with variability corresponding to the range of measured assimilation efficiencies in pulse-chase feeding experiments. Only data for exposures representing an increase in sediment metal concentrations are included: Ag, As and $\mathrm{Zn}$ for Restronguet Creek sediments (multiplication symbol), As and $\mathrm{Zn}$ for Dulas Bay (open triangle) and $\mathrm{As}, \mathrm{Cd}$ and $\mathrm{Zn}$ for the Gannel (filled circle). Lines represent a deviation of $2 \times$ above or below the $1: 1$ relationship 
variation range, with a scatter distribution around the 1:1 relationship indicating that predictions obtained with the generic model are in good agreement with laboratorymeasured bioaccumulated concentrations. The slope for the regression of model-predicted versus laboratory bioaccumulated concentrations for the whole time series is $1.15\left(R^{2}=0.70\right)$, whereas it decreases to $1.09\left(R^{2}=0.77\right)$ when only considering data for 30 days of exposure. The model predicted accurately the increase in the bioaccumulated concentrations of $\mathrm{As}$ and $\mathrm{Zn}$ in worms exposed to the Restronguet Creek sediments, whereas model predictions of $\mathrm{Ag}$ concentrations were below the concentrations measured in laboratory-exposed worms (Fig. 4). The predicted bioaccumulated concentrations of As for the Dulas and Gannel exposure were also in good agreement with measured concentrations, whereas Cd concentrations were also accurately predicted for the Gannel exposure, with some disagreement on data for 20 days which was associated with the low concentration measured in laboratory-exposed worms when compared with measurements on days 10 and 30 (see data in Figs. S2 and S3 of the "Electronic supplementary material").
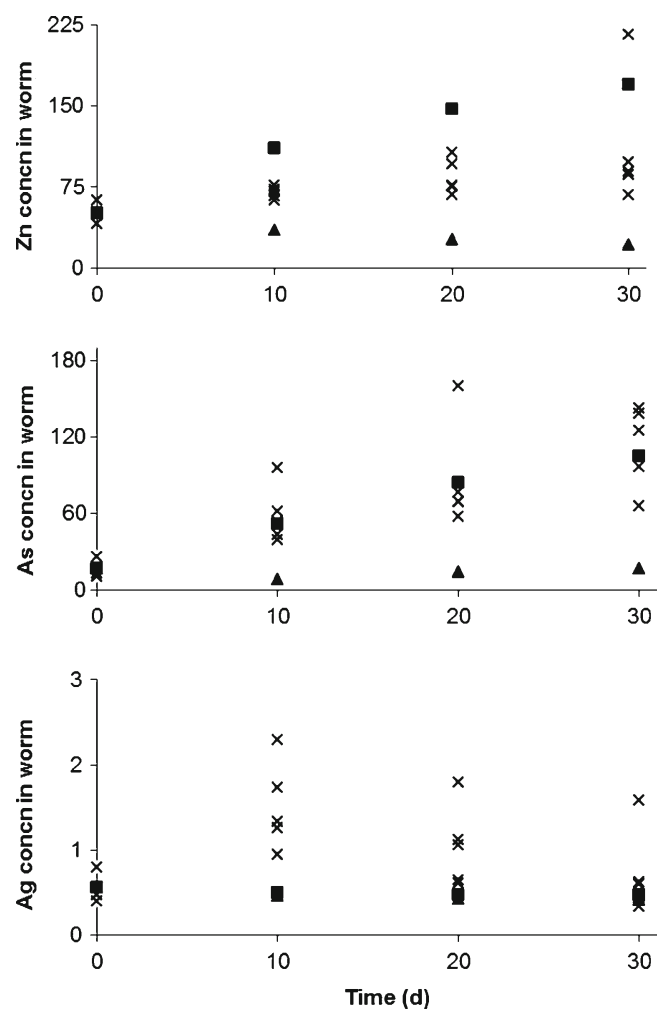

Fig. 4 Bioaccumulated concentrations $\left(\mu \mathrm{gg}^{-1}\right)$ measured in individuals of A. marina from laboratory exposures to Restronguet Creek sediments (multiplication symbol) and model-predicted concentrations in the absence of sediment ingestion (filled triangle) and with an optimal ingestion rate as calculated following Cammen (1980) (filled square)

\section{Discussion}

Deposit-feeding polychaetes are, together with bivalves, among the most commonly recommended and used marine benthic invertebrates for the assessment of bioaccumulation from sediments (US EPA 2000). Deposit-feeding polychaetes are sought as suitable indicators of sediment contamination as they are among the most abundant taxon in benthic sampling, they live in intimate contact with sediment, where they live and feed, and they are relatively inert ensuring chronic exposure (Dean 2009). The marine polychaete A. marina is a regular in marine ecotoxicology (Bat 2005) and in principle meets many of the requirements for test organism selection for sediment bioaccumulation tests. Although culturing of this species has been only achieved to a limited extent (WO/2003/007701), wild populations are available all year round. A. marina withstands the long-term exposure periods necessary for bioaccumulation tests, is tolerant to a wide range of sediment and water quality characteristics and provides adequate biomass for chemical analyses. In summary, it is a serious candidate marine species for which ingested sediment is an important (if not major) route of metal uptake. In this study, we explored the performance of A. marina in metal bioaccumulation assessment through the direct comparison of results obtained from three different approaches potentially useful in a regulatory context (US EPA 2000; ICMM 2007): direct measurements of metal bioaccumulation in laboratoryexposed organisms, measured concentrations in fieldcollected organisms and biodynamic model predictions of bioaccumulated concentrations of metals for which values of the physiological parameters of metal accumulation have been derived in previous works.

Among the most important issues for laboratory protocols, together with the selection of test species, is exposure duration. Relatively simple and inexpensive short-term tests can be used to identify qualitatively which sediment compounds will bioaccumulate, whereas longer-term tests of a minimum of 28 days are required for quantitative estimates of accumulated tissue concentrations for these compounds (US EPA 2000). In our laboratory experiments with $A$. marina, 10 days was enough to register a significant bioaccumulation potential when sediment concentrations were conspicuously high (i.e., Restronguet Creek). For sediment concentrations still high but not as high as in Restronguet Creek, such as $\mathrm{As}$ and $\mathrm{Pb}$ in the Gannel estuary or $\mathrm{Cu}$ in Dulas Bay, 30 days instead of 10 days was needed to register a significant increase in bioaccumulation. This exposure period, however, proved to be insufficient to reach a steady state under the conditions of this study as demonstrated by the steady increase in bioaccumulated concentration over the period of observations and the comparison with concentrations measured in field-collected organisms. 
A total of 28 days is the standard recommended duration for bioaccumulation tests for the assessment of organic and organometallic compounds because previous results indicate that tissue residues are typically within $80 \%$ of steady-state concentrations, although some uncertainty remains as to how representative a 28-day exposure is of steady-state conditions, in particular for very high hydrophobic organic compounds (see review in Van Geest et al. (2010)). The proportion of the metal concentrations reached by the experimental worms over the laboratory exposure in our study compared to the concentrations measured in fieldcollected worms was $\sim 30 \%$ for $\mathrm{Cu}$ for Dulas Bay sediment and $\sim 30 \%$ for $\mathrm{Pb}$ and $\sim 60 \%$ for As for the Gannel sediment, suggesting that an exposure period of $\sim 90, \sim 90$ and $\sim 60$ days, respectively, would be needed to provide a quantitative estimate of steady-state bioaccumulated metal concentrations derived from the sediments considered here.

Certain considerations apply when interpreting the results for Zn. Zinc is an essential metal that A. marina appears to regulate to a relatively constant body concentration over a range of sediment $\mathrm{Zn}$ bioavailabilities (Turner et al. 2008; Casado-Martinez et al. 2009a). This ability to regulate the body concentration of $\mathrm{Zn}$ is clearly overcome in worms exposed to the Restronguet Creek sediments as has been described for the population of the polychaete Nereis diversicolor living at this site (Rainbow et al. 2009). There is not, however, a steady increase in the bioaccumulated concentrations of $\mathrm{Zn}$ in worms exposed to the Gannel and Dulas Bay sediments over the laboratory exposure period but there was a relative increase (although not statistically significant) after 30 days of exposure compared to unexposed worms and worms exposed to the Thames sediment (the control exposure). The field population living in the Gannel estuary did not show raised bioaccumulated $\mathrm{Zn}$ concentrations, but the population in Dulas Bay actually did but on threefoldhigher sediment concentrations $\left(>600 \mu \mathrm{gg}^{-1}\right.$; CasadoMartinez et al. 2009b). An extended exposure period may also be required to produce a clearer picture of the breakdown of the $\mathrm{Zn}$ regulation capacity of $A$. marina and allow the eventual attainment of steady-state $\mathrm{Zn}$ body concentrations after an initial period of physiological adaptation of the worms.

Differences in bioaccumulated metal concentrations between laboratory- and field-collected worms may be attributable not only to test duration but also to changes in sediment composition, differences in temperature affecting metabolic rates and differences in the organisms' behaviour (Van Geest et al. 2011). Differences associated with changes in sediment concentrations among samplings have been considered here through the development of BSAFs, but this factor is only responsible for minor differences (for example, $\mathrm{Cu}$ bioaccumulation for the Gannel sediments and $\mathrm{Ag}$ for the Thames sediments). Mortality or loss of biomass are not endpoints usually measured (and thus reported) in bioaccumulation studies, but they may provide information about possible avoidance or reduced ingestion of contaminated sediment, altering contaminant exposure and influencing the ability of organisms to achieve a steady state (Van Geest et al. 2010). Taking into consideration that it took up to 3 days for the worms to acclimatise to their new habitat and feed regularly in the new sediment, a feature that has been observed for several other polychaetes under laboratory exposures (Weston et al. 2000; Timmermann and Andersen 2003; Janssen et al. 2010), and that A. marina decreases feeding activity at increasing concentrations of sediment-bound contaminants to the point that feeding activity is being considered a suitable endpoint in toxicity tests (Timmerman and Andersen 2003; Bat 2005; Allen et al. 2007), it may be reasonable to suppose that this feature is an issue for the interpretation of bioaccumulation test results on deposit-feeding polychaetes such as A. marina.

Even if biodynamic models can provide forecasts that are in the scale of measured concentrations in both field-collected organisms and organisms exposed in the laboratory to metal-contaminated sediments, a model that uses average values of physiological parameters and physico-chemical measurements is a generalisation that may not capture site-specific differences in metal bioavailability. However, there is great potential for testing different hypotheses and scenarios (Casado-Martinez et al. 2010b); this is one of the advantages of using a model, namely, that it can be used to estimate patterns of bioaccumulation of specific substances under specified exposure conditions (US EPA 2000). According to our previous results, ingested sediment is an important (often much the major) source of metals for the polychaete A. marina, with the strongest determinants for the model being ingestion rate, assimilation efficiency and metal concentration in sediments (CasadoMartinez et al. 2009b, 2010b). In the absence of direct measurements of ingestion rates, we used estimations according to the model developed by Cammen (1980), which is based on the inverse correlation between OM content and the ingestion of total dry material, dependent on organism size. However, there is a good possibility that this ingestion rate may not represent the feeding behaviour of the worms under laboratory exposures. To test this hypothesis, we calculated model predictions for the complete range of ingestion rates, including consideration of the absence of sediment ingestion as a worst case scenario. The average rate of net accumulation of metals for the period of observations, in particular over the last 10 days of observations, is captured using Cammen's ingestion rate assumptions, and the range of predicted concentrations captures the range of measured concentrations. This is observed for the Restronguet Creek sediment (see Fig. 4) and also for the Gannel and Dulas Bay sediment exposures (data 
shown in Figs. S1-S3 of the "Electronic supplementary material"). The exception to the good fit of model-predicted and measured concentrations is Ag. The Thames estuary presented higher concentrations of Ag than the Gannel estuary and Dulas Bay; thus, an elimination of bioaccumulated $\mathrm{Ag}$ concentrations would be expected over the laboratory exposure to these two sediments. However, bioaccumulated $\mathrm{Ag}$ concentrations measured in laboratory-exposed worms were usually higher than those measured in field-collected worms, and the time course of bioaccumulated $\mathrm{Ag}$ concentrations in worms does not show a decreasing trend for any of these two sediments. Two factors may have contributed to these results to some extent: an increased accumulation of $\mathrm{Ag}$ from the dissolved phase associated with an increase in dissolved Ag concentrations due to sediment resuspension during laboratory experiments and a decreased elimination rate over the laboratory exposure compared to those previously quantified and used here for the modelling exercise (Figs. S1a-S3a of the "Electronic supplementary material").

Growth rates are generally introduced into the biodynamic modelling of steady-state concentrations as the bioaccumulated concentrations are diluted by the increase of tissue weight in the organism. In our previous modelling exercises of steady-state concentrations in field-collected worms, we used a standard growth rate of 0.02 day $^{-1}$, and this term was needed to provide accurate steady-state predicted concentrations. We did not initially consider a growth rate term for modelling concentrations in laboratory-exposed worms to allow for any changes in body weight over the exposure duration. In fact, body wet weight in individual worms ranged from -30 to $+20 \%$ with respect to the weight of the worm on day 0 , which translates into growth rates varying from -0.28 to $0.03 \mathrm{day}^{-1}$. The introduction of these growth rates into the model would translate into higher and lower forecasts, respectively, and the same applies for the correction of the measured concentrations in laboratoryexposed organisms. This factor could have also contributed to the increased $\mathrm{Ag}$ bioaccumulated concentrations in laboratory-exposed worms. When we took into consideration the correction for this factor, the effect on the fit between laboratory, field and modelling data was in fact negligible if any (data not shown), corroborating that the decrease in biomass in deposit feeders used in laboratory tests has uncertain and unpredictable effects for the interpretation of bioaccumulation results (Ciparis and Hale 2005; Van Geest et al. 2010, 2011).

\section{Conclusions}

It is widely accepted that the easiest and most relevant measure for quantifying steady-state concentrations is provided by quantifying concentrations in individuals collected in the field from the site at issue. For assessments of hypothetical situations, for example, in ex situ characterisations, it may not be possible to obtain field-collected tissues. If this is the case, standard laboratory bioassays using individuals from a control site exposed to field-collected sediments are easy to perform and offer unique qualitative and quantitative measurements of metal bioaccumulation from sediments. Still it is common among deposit-feeding polychaetes to show symptoms of stress in feeding and growth not only caused by sediment contamination but also associated with laboratory handling and acclimation. This feature may result in a high variability in the measured bioaccumulated metal concentrations that should be considered for the interpretation of test results, in particular for short-term exposures.

Laboratory protocols for bioaccumulation tests are relatively well standardised and 28 days is the most common exposure duration considered, but the significance of the 28day protocol seems compromised for most of the metals and sediments considered in this study. A longer temporal sampling strategy of laboratory-exposed organisms is a suitable approach to ensure steady-state, but routine implementation of such an approach would entail greater time and costs. Appropriately designed models such as biodynamic modelling are a cost-effective alternative methodology to estimate both the extent and pattern of bioaccumulation under specified exposure conditions. Such models are able to provide predictions of steady-state concentrations, although their use still needs to be further extended and validated to consider site-specific physiological constraints and metal bioavailability issues.

Acknowledgments This project was financially supported by the European Community's Seventh Framework Program through a Marie Curie Intra-European Fellowship to MCCM (FP7/2007-2013) under grant agreement no. PIEF-GA-2008-219781 and the Ramon Areces Foundation. MCCM acknowledges the financial support from the multidisciplinary research and education project Environmental Waste Management (EWMA) during the writing of this manuscript at the University of Tromsø.

\section{References}

Allen YT, Thain JE, Haworth S, Barry J (2007) Development and application of long-term sublethal whole sediment tests with Arenicola marina and Corophium volutator using ivermectin as the test compound. Environ Pollut 146:92-99

AMST, American Society of Testing and Materials (2010) Standard guide for determination of the bioaccumulation of sedimentassociated contaminants by benthic invertebrates. E-1688-00a. Annual Book of ASTM Standards 11.05, 1077-1130

Barwick M, Maher W (2003) Biotransference and biomagnification of selenium, copper, cadmium, zinc, arsenic and lead in a temperate seagrass ecosystem from Lake Macquarie Estuary, NSW, Australia. Mar Environ Res 56:471-502

Bat L (2005) A review of sediment toxicity bioassays using the amphipods and polychaetes. Turk J Fish Aquat Sci 10:119-139 
Bennett ER, Steevens JA, Lotufo GR, Paterson G, Drouillard KG (2011) Novel control and steady-state correction method for standard 28-day bioaccumulation tests using Nereis virens. Environ Toxicol Chem 30:1366-1375

Bernds D, Wubben D, Zauke G-P (1998) Bioaccumulation of trace metals in polychaetes from the German Wadden Sea: evaluation and verification of toxicokinetic models. Chemosphere 37:2573-2587

Boyle D, Brix KV, Amlund H, Lundebye AK, Hogstrand C, Bury NR (2008) Natural arsenic contaminated diets perturb reproduction in fish. Environ Sci Technol 42:5354-5360

Cammen LM (1980) Ingestion rate: an empirical model for aquatic deposit feeders and detritivores. Oecologia 44:303-310

Casado-Martinez MC, Smith BD, DelValls TA, Rainbow PS (2009a) Pathways of trace metal uptake in the lugworm Arenicola marina. Aquat Toxicol 92:9-17

Casado-Martinez MC, Smith BD, DelValls TA, Luoma SN, Rainbow PS (2009b) Biodynamic modelling and the prediction of accumulated trace metal concentrations in the polychaete Arenicola marina. Environ Pollut 157:2743-2750

Casado-Martinez MC, Smith BD, Luoma SN, Rainbow PS (2010a) Metal toxicity in a sediment-dwelling polychaete: threshold body concentrations or overwhelming accumulation rates? Environ Pollut 158:3071-3076

Casado-Martinez MC, Smith BD, Luoma SM, Rainbow PS (2010b) Bioaccumulation of arsenic from water and sediment by a depositfeeding polychaete (Arenicola marina): a biodynamic modelling approach. Aquat Toxicol 98:34-43

Chapman PM, Anderson J (2005) A decision-making framework for sediment contamination. Integr Environ Assess Manag 1:163-173

Chen Z, Mayer LM (1999) Sedimentary metal bioavailability determined by the digestive constraints of marine deposit feeders: gut retention time and dissolved amino acids. Mar Ecol Prog Ser 176:139-151

Cheung MS, Wang W-X (2008) Analyzing biomagnification of metals in different marine food webs using nitrogen isotopes. Mar Pollut Bull 56:2082-2088

Ciparis S, Hale RC (2005) Bioavailability of polybrominated diphenyl ether flame retardants in biosolids and spiked sediment to the aquatic oligochaete, Lumbriculus variegatus. Environ Toxicol Chem 24:916-925

Croteau MN, Luoma SN, Steward AR (2005) Trophic transfer of metals along freshwater food webs: evidence of cadmium biomagnification in nature. Limnol Oceanogr 50:1511-1519

De Jonge M, Dreesen F, De Paepe J, Blust R, Bervoets L (2009) Do acid volatile sulphides (AVS) influence the accumulation of sediment-bound metals to benthic invertebrates under natural field conditions? Environ Sci Technol 43:4510-4516

Dean HK (2009) The use of polychaetes (Annelida) as indicator species of marine pollution: a review. Rev Biol Trop Int J Trop Biol 56:11-38

Fairbrother A, Wenstel R, Sappington K, Wood W (2007) Framework for metals risk assessment. Ecotox Environ Saf 68:145-227

ICMM (2007) MERAG: metals environmental risk assessment guidance. ISBN: 978-0-955-3591-2-5

Jæger I, Hop H, Gabrielsen GW (2009) Biomagnification of mercury in selected species from an Arctic marine food web in Svalbard. Sci Total Environ 407:4744-4751

Janssen E, Croteau M-N, Luoma SN, Luthy RG (2010) Measurement and modelling of polychlorinated biphenyl bioaccumulation from sediment for the marine polychaete Neanthes arenaceodentata and response to sorbent amendment. Environ Sci Technol 44:2857-2863

Kaag NHBM, Scholten MCT, Van Straalen NM (1998) Factors affecting PAH residues in the lugworm Arenicola marina, a sediment feeding polychaete. J Sea Res 40:251-261

Kalman J, Riba I, DelValls TA, Blasco J (2012) Bioaccumulation and effects of metals bound to sediments collected from Gulf of Cadiz (SW Spain) using the polychaete Arenicola marina. Arch Environ Contam Toxicol 62:22-28
Lawrence A, McAllon KM, Mason RP, Mayer LM (1999) Intestinal solubilisation of particle-associated organic and inorganic mercury as a measure of bioavailability to benthic invertebrates. Environ Sci Technol 33:1871-1876

Lee BG, Lee JS, Luoma SN, Choi HJ, Koh CH (2000) Influence of acid volatile sulfide and metal concentrations on metal bioavailability to marine invertebrates in contaminated sediments. Environ Sci Technol 34:4517-4523

Luoma SN, Rainbow PS (2005) Why is metal bioaccumulation so variable? Biodynamics as a unifying concept. Environ Sci Technol 37:1921-1931

Mackay D, Fraser A (2000) Bioaccumulation of persistent organic chemicals: mechanisms and models. Environ Pollut 110:375391

Morales-Caselles C, Ramos J, Riba I, DelValls TA (2008) Using the polychaete Arenicola marina to determine toxicity and bioaccumulation of PAHs bound to sediments. Environ Monit Assess 142:219-226

OSPAR (1995) Protocols on methods for the testing of chemicals used in the offshore industry. Oslo and Paris Commissions, London

Rainbow PS, Smith BD, Luoma SN (2009) Differences in trace metal bioaccumulation kinetics among populations of the polychaete Nereis diversicolor from metal-contaminated estuaries. Mar Ecol-Prog Ser 376:173-184

Rainbow PS, Smith BD, Casado-Martinez MC (2011) Biodynamic modeling of the bioaccumulation of arsenic by the polychaete Nereis diversicolor. Environ Chem 8:1-8

Ramos-Gomez J, Viguri JR, Luque A, Vale C, Martin-Diaz ML, DelValls TA (2011a) Sediment-quality assessment using the polychaete Arenicola marina: contamination, bioavailability, and toxicity. Arch Environ Contam Toxicol 61:578-589

Ramos-Gomez J, Martins M, Raimundo J, Vale C, Martin-Diaz ML, DelValls TA (2011b) Validation of Arenicola marina in field toxicity bioassays using benthic cages: biomarkers as tools for assessing sediment quality. Mar Pollut Bull 62:15381549

Thain J, Bifield S (2001) Biological effects of contaminants: sediment bioassay using the polychaete Arenicola marina. ICES Techniques in Marine Environmental Sciences 29, pp. 16

Thain J, Davies IM, Rae GH, Allen YT (1997) Acute toxicity of ivermectin to the lugworm Arenicola marina. Aquaculture 159:47-52

Timmermann K, Andersen O (2003) Bioavailability of pyrene to the deposit-feeding polychaete Arenicola marina: importance of sediment versus water uptake routes. Mar Ecol-Prog Ser 246:163-172

Townsend AT, Palmer AS, Stark SC, Samson C, Scouller RC, Snape I (2007) Trace metal characterisation of marine sediment reference materials MESS-3 and PACS- 2 in dilute extracts. Mar Pollut Bull $54: 226-246$

Turner A, Singh N, Millard L (2008) Bioaccessibility and bioavailability of $\mathrm{Cu}$ and $\mathrm{Zn}$ in sediment contaminated by antifouling paint residues. Environ Sci Technol 42:8740-8746

US Environmental Protection Agency (2000) Bioaccumulation testing and interpretation for the purpose of sediment quality assessment: status and needs. EPA 823-R-00-001. Washington, DC

Van Geest JL, Poirier DG, Sibley PK, Solomon KR (2010) Measuring bioaccumulation of contaminants from field-collected sediments in freshwater organisms: a critical review of laboratory methods. Environ Toxicol Chem 29:2391-2401

Van Geest JL, Poirier DG, Sibley PK, Solomon KR (2011) Validation of Ontario's laboratory-based bioaccumulation methods with in situ field data. Environ Toxicol Chem 30:950-958

Weston DP, Pery DL, Gulmann LK (2000) The role of ingestion as a route of contaminant bioaccumulation in a deposit-feeding polychaete. Arch Environ Contam Toxicol 38:446-454 